American University Washington College of Law

Digital Commons @ American University Washington College of

Law

Articles in Law Reviews \& Other Academic Journals

Scholarship \& Research

2006

\title{
Beyond a Snapshot: Preventing Human Trafficking in the Global Economy
}

Janie Chuang

American University Washington College of Law, jchuang@wcl.american.edu

Follow this and additional works at: https://digitalcommons.wcl.american.edu/facsch_lawrev

Part of the Immigration Law Commons, International Humanitarian Law Commons, Law and Gender Commons, and the Sexuality and the Law Commons

\section{Recommended Citation}

Chuang, Janie, "Beyond a Snapshot: Preventing Human Trafficking in the Global Economy" (2006). Articles in Law Reviews \& Other Academic Journals. 1053.

https://digitalcommons.wcl.american.edu/facsch_lawrev/1053

This Article is brought to you for free and open access by the Scholarship \& Research at Digital Commons @ American University Washington College of Law. It has been accepted for inclusion in Articles in Law Reviews \& Other Academic Journals by an authorized administrator of Digital Commons @ American University Washington College of Law. For more information, please contact kclay@wcl.american.edu. 


\title{
Beyond a Snapshot: Preventing Human Trafficking in the Global Economy
}

\author{
Janie ChuAng*
}

\begin{abstract}
Current legal responses to the problem of human trafficking often reflect a deep reluctance to address the socioeconomic root causes of the problem. Because they approach trafficking as an act (or series of acts) of violence, most responses focus predominantly on prosecuting traffickers, and to a lesser extent, protecting trafficked persons. While such approaches might account for the consequences of trafficking, they tend to overlook the broader socioeconomic reality that drives trafficking in human beings. Against this backdrop, this article seeks to reframe trafficking as a migratory response to current globalizing socioeconomic trends. It argues that, to be effective, countertrafficking strategies must target the underlying conditions that impel people to accept dangerous labor migration assignments. The article recommends that existing counter-trafficking strategies be assessed with a view to assessing their potential for long-term effectiveness. It also advocates strategic use of the nondiscrimination principle to promote basic economic, social, and cultural rights, the deprivation of which has sustained the trafficking phenomenon.
\end{abstract}

\section{INTRODUCTION}

Within the last decade, governments have hastened to develop international, regional, and national laws to combat the problem of human trafficking, i.e., the recruitment or movement of persons for forced labor or slavery-like practices. Legal responses to the problem typically adopt a three-prong framework focused on prosecuting traffickers, protecting trafficked persons, and preventing trafficking. In practice, however, these responses emphasize the prosecution of traffickers and, to a lesser extent, the protection of their victims.

*Practitioner-in-Residence, American University, Washington College of Law. I would like to thank the other Symposium participants for their insightful comments on an early version of this a rricle. I have also benefited from invaluable comments on drafts of this article from Christiana Ochoa and Ashley Parrish. I am also grateful to Douglas Skelley, Elena Dicus, and Brian Clifford for their exceptional editing. 
Most legal frameworks address trafficking as an act (or a series of acts) of violence, with the perpetrators to be punished and the victims to be protected and reintegrated into society. While such responses might account for the consequences of trafficking, they tend to overlook its causes - that is, the broader socioeconomic conditions that feed the problem. Oft-repeated pledges to prevent trafficking by addressing its root causes seldom evolve from rhetoric into reality.

More often than not, trafficking is labor migration gone horribly wrong in our globalized economy. Notwithstanding its general economic benefits, globalization has bred an ever-widening wealth gap between countries, and between rich and poor communities within countries. ${ }^{1}$ This dynamic has created a spate of "survival migrants"' who seek employment opportunities abroad as a means of survival as jobs disappear in their countries of origin. The desperate need to migrate for work, combined with destination countries tightening their border controls (despite a growing demand for migrant workers), render these migrants highly vulnerable to trafficking. For women in particular, this vulnerability is exacerbated by wellentrenched discriminatory practices that relegate women to employment in informal economic sectors and further limit their avenues for legal migration.

Governments have been deeply reluctant, however, to view trafficking in this broader frame-that is, as a problem of migration, poverty, discrimination, and gender-based violence. They have tended to view trafficking as a "law and order" problem requiring an aggressive criminal justice response. Emerging studies reveal the drawbacks of this myopia. Notwithstanding the hundreds of millions of dollars already invested in the criminal justice response to the problem, we have yet to see an appreciable reduction in the absolute numbers of people trafficked worldwide. ${ }^{3}$ And even in the rare cases where trafficked persons have received rights-

1. See United Nations High Commissioner for Human Rights, Report of the United Nations High Commissioner, I 6, delivered to the Economic and Social Council, U.N. Doc. E/1999/96 (July 29, 1999) (noting that while globalization has had its benefits, there is a "clear trend towards a smaller percentage of the population receiving a greater share of wealth, while the poorest simultaneously lose ground"); see generally Executive Summary to U.N. Econ. \& Soc. Council [ECOSOC], Comm'n on Human Rights, Integration of the Human Rights of Women and the Gender Perspective: Violence Against Women, at 4, U.N. Doc. E/CN.4/2000/68 (Feb. 29, 2000) (prepared by Radhika Coomaraswamy) [hereinafter Coomaraswamy Report].

2. Bimal Ghosh, Huddled Masses and Uncertain Shores: Insights into Irregular MigraTION 35 (1998).

3. The number of people trafficked remains staggering. The International Labour Organization (ILO) estimates that 2.5 million people are trafficked at any point in time, generating $\$ 32$ billion in profits for organized crime. International Labour Office, A Global Alliance Against 
protective treatment and aftercare, they nonetheless are left facing the socioeconomic conditions that rendered them vulnerable to abuse in the first instance.

This article explores governments' reluctance to address trafficking in its broader socioeconomic context, and offers both a plea and a proposal for more comprehensive approaches to trafficking. Because close examination of these issues is beyond the scope of this short symposium piece, this article aims only to lay a foundation for further thought and discussion in this area. This article problematizes current approaches to trafficking by reframing the problem of trafficking as a global migratory response to current globalizing socioeconomic trends. It argues that, to be effective, counter-trafficking strategies must also target the underlying conditions that impel people to accept dangerous labor migration assignments in the first place. The article then examines how the international legal response to the problem is, as yet, inadequate to the task of fostering longterm solutions. Moreover, by failing to assess the long-term implications of existing counter-trafficking strategies, these responses risk being not only ineffective, but counterproductive. Observing the need for more focused inquiry into prevention strategies, the article advocates strategic use of the nondiscrimination principle to give more meaningful application to basic economic, social, and cultural rights, the violation of which sustains the trafficking phenomenon. ${ }^{4}$

Given the enduring nature of socioeconomic deprivation in many parts of the world, it is easy to dismiss calls for substantive prevention strategies as too lofty or impracticable. But the reality that millions of lives remain at risk for trafficking demands that we embrace this challenge.

\section{Globalization, Migration, and Trafficking}

While the problem of human trafficking has captured widespread public attention in recent years, it has mostly been in response to narrow portrayals of impoverished women and girls trafficked into the sex industry by shady figures

\footnotetext{
Forced Labour: Global Report Under the Follow-up to the ILO Declaration on Fundamental Principles and Rights at Work 46, 55 (2005) [hereinafter ILO Global Report].

4. Michael J. Dennis \& David P. Stewart, Justiciability of Economic, Social, and Cultural Rights: Should There Be an International Complaints Mechanism to Adjudicate the Rights to Food, Water, Housing, and Health?, 98 Am. J. INT'L L. 462, 464 (2004).
} 
connected to organized crime. ${ }^{5}$ Considerably less attention has been devoted to the widespread practice of the trafficking of women, men, and children into exploitative agricultural work, construction work, domestic work, or other nonsexual labor. ${ }^{6}$ Most portrayals-particularly of sex trafficking-depict trafficking as an act (or series of acts) of exploitation and violence, perpetrated by traffickers and suffered by desperate and poverty-stricken victims. While accurate in some respects, such depictions are incomplete. The problem of trafficking begins not with the traffickers themselves, but with the conditions that caused their victims to migrate under circumstances rendering them vulnerable to exploitation. Human trafficking is but "an opportunistic response" to the tension between the economic necessity to migrate, on the one hand, and the politically motivated restrictions on migration, on the other. ${ }^{7}$ This section offers a broader view of trafficking as a product of the larger socioeconomic forces that feed the "emigration push" and "immigration pull" toward risky labor migration practices in our globalized economy.

\section{A. Emigration "Push" Factors}

Globalization and the opening of national borders have led not only to greater international exchange of capital and goods, but also to increasing labor migration. ${ }^{8}$ The wealth disparities created by our globalized economy have fed increased intra- and transnational labor migration as livelihood options disappear in less wealthy countries and communities. ${ }^{9}$ As Anne Gallagher explains,

5. See, e.g., Peter Landesman, The Girl Next Door, N.Y. Times MAG., Jan. 25, 2004, at 30; Nicholas D. Kristof, Girls for Sale, N.Y. TIMes, Jan. 17, 2004, at A15; Nicholas D. Kristof, Bargaining for Freedom, N.Y. Times, Jan. 21, 2004, at A27; Nicholas D. Kristof, Loss of Innocence, N.Y. Times, Jan. 28, 2004, at A25; Nicholas D. Kristof, Stopping the Traffickers, N.Y. Times, Jan. 31, 2004, at A17.

6. David A. Feingold, Think Again: Human Trafficking, Foreign PoL'y, Sept.-Oct. 2005, at 26.

7. ILO Global Report, supra note 3, at 46.

8. Comm. on Feminism and Int'l Law, Int'l Law Ass'n, Women and Migration: Interim REPORT ON TRAFFICKINC IN WOMEN 2 (2004), available at http:/www.ila-hq.org/pdf/Feminism\% 20\&\%20International\%20Law/Report\%202004.pdf.

9. See generally Gноsн, supra note 2 (distinguishing between survival migration and opportunityseeking migration); Mike Kaye, Anti-Slavery Int'L, The Migration-Trafficking Nexus: Combating Trafficking Through the Protection of Migrants' Human Rights 13 (2003), availableat http://www.antislavery.org/homepage/resources/the\% 20 migration $\% 20$ trafficking $\% 20$ nexus $\%$ 202003.pdf. 
trafficking lies at one extreme end of the emigration continuum, ${ }^{10}$ where the migration is for survival - that is, escape from economic, political, or social distress-as opposed to opportunity-seeking migration-that is, merely a search for better job opportunities. Contrary to the popular, sensationalized image of trafficked persons as either kidnapped or coerced into leaving their homes, more often than not the initial decision to migrate is a conscious one. "Yet, the decision to uproot oneself, leave one's home, and migrate elsewhere cannot be explained as a straightforward "rational choice by persons who assess the costs and benefits of relocating"; rather, an understanding of this decision must account for "macro factors that encourage, induce or often, compel migration."12 "Push" factors are not created by the traffickers so much as this broader context, i.e., the economic impact of globalization. ${ }^{13}$ Traffickers, being opportunity-seeking by nature, simply take advantage of the resulting vulnerabilities to make a profit.

Because women are over-represented among survival migrants, it is not surprising that women comprise the vast majority of trafficked persons. Recent estimates from the U.S. State Department place the figure at 80 percent. ${ }^{14}$ This gender disparity is often attributed to the "feminization of poverty" arising from the failure of existing social structures to provide equal and just educational and employment opportunities for women. ${ }^{15}$ While women migrate in response to economic hardship, they also migrate to flee gender-based repression. ${ }^{16}$ Women will accept dangerous migration arrangements in order to escape the consequences of entrenched discrimination against women, including unjust or unequal employment, gender-based violence, and the lack of access to basic resources for women. ${ }^{17}$

10. Anne Gallagher et al., Consideration of the Issue of Trafficking: Background Paper 16-17 (2002) (citing Gнosh, supra note 2, at 35), available at http:/www.nhri.net/pdf/ ACJ\%20Trafficking\%20Background\%20Paper.pdf.

11. Feingold, supra note 6 , at 28.

12. Patrick A. Taran, Human Rights of Migrants: Challenges of the New Decade, INT'L MigraTion, Vol. 38, No. 6 (Special Issue 2), Feb. 2001 , at 12.

13. See Saskia Sassen, Women's Burden: Counter-Geographies of Globalization and the Feminization of Survival, 71 NoRdic J. INT'L. L. 255, 257 (2002).

14. U.S. Dep't of State, Trafficking in Persons Report 6 (2005) [hereinafter 2005 TIP RePORT], available at http://www.state.gov/documents/organization/47255.pdf.

15. Coomaraswamy Report, supra note I, II 58.

16. Id. II 54-60.

17. See id. \ 60. 
As the former U.N. Special Rapporteur on Violence against Women, Radhika Coomaraswamy, explains, gender discrimination underlying these migratory flows is maintained through the collusion of factors at the market, state, community, and family levels. ${ }^{18}$ Women's role in the market tends to be derived from traditional sex roles and division of labor, e.g., housekeeping, childcare, and other unpaid/underpaid subsistence labor. At the community level, women face discrimination through "uneven division of wage labour and salaries, citizenship rights and inheritance rights," 19 as well as certain religious and customary practices, which, reinforced by state policies, further entrench and validate the discrimination and perpetuate the cycle of oppression of women. At the family level, gender discrimination manifests, for example, in "the preference for male children and [a] culture of male privilege [that] deprives girls and women of access to basic and higher education." ${ }^{20}$

Women's lack of rights and freedoms is further exacerbated by certain (macro-level) globalizing trends that have produced an environment conducive to trafficking. Professor Jean Pyle has identified these trends to include: (1) the shift to "export-oriented" approaches, where the production of essential goods is targeted for external trade rather than countries' own internal markets; (2) the entry of multinational corporations (MNCs) into developing countries and the MNCs' extensive networks of subcontractors; (3) structural adjustment policies (SAPs) mandated by the International Monetary Fund (IMF) or the World Bank (WB) as a condition for loans, requiring governments to open their markets to further financial and trade flows and to undertake austerity measures which fall heavily on the poor, particularly women; and (4) the shift in the structure of power at the international level-that is, the rise in the power of international institutions focused on markets (such as MNCs, the IMF, the WB, and the World Trade Organization (WTO)) relative to those that are more peoplecentered and concerned with sustainable human development (such as the ILO, many U.N. agencies, and nongovernmental organizations (NGOs)). ${ }^{21}$

These global restructuring trends can have harsh effects on women in developing countries-either fostering exploitative conditions for women work-

18. Id. II 57.

19. Id.

20. Id.

21. See Jean L. Pyle, How Globalization Fosters Gendered Labor Networks and Trafficking $2-$ 3 (Nov 13-15, 2002) (unpublished manuscript), available at http://www.hawaii.edu/global/ projects_activities/Trafficking/Pyle.doc. 
ing in the formal sector, or pushing women directly into work in the informal sector. To the (limited) extent that women are even permitted to work in the formal economy-such as in small businesses or in agriculture-they are often forced out of business by the cheaper imports that trade liberalization brings. ${ }^{22}$ As the manufacturing and service industries have entered developing economies, workers in these countries have joined the "global assembly line"; indeed, many MNCs prefer female workers due to their lower cost and lesser likelihood of resisting adverse working conditions. ${ }^{23}$ While MNCs provide a source of jobs, they also create "a pool of low-skilled wage labour exposed to standards of western consumption and representing a potential source of emigration." 24

Structural adjustment policies add to the pressure on women to migrate in search of work. These policies, which require governments to cut programs and reduce expenditures on social services, cause women to take on additional income-earning activities in order to maintain their families' standards of living, as governments decrease benefits in housing, health care, education, food, and fuel subsidies. ${ }^{25}$ This often pushes women to work in the unregulated, informal sectors, thus contributing to the rise of gendered-labor networks-prostitution or sex work, domestic work, and low-wage production work. ${ }^{26}$ Women often migrate in search of jobs in these largely unregulated sectors, rendering them all the more vulnerable to traffickers.

Compelled to leave their homes in search of viable economic options, previously invisible, low-wage-earning, migrant women are now playing a critical role in the global economy. Through this dynamic-which Professor Saskia Sassen terms the "feminization of survival"-entire households, communities, and even some governments are increasingly dependent on these women for their economic survival. ${ }^{27}$ The changes to the international political economy have caused a number of states in the global south, especially in Asia, which is grappling with foreign debt and rising unemployment, to play a "courtesan's

22. Id. at 5 .

23. Id.

24. Christina Boswell \& Jeff Crisp, Poverty, International Migration and Asylum 6 (United Nations Univ., World Inst. for Dev. Econ. Research, Policy Brief No. 8, 2003).

25. See Sassen, supra note 13, at 263.

26. See U.N. Div. for the Advancement of Women, The Netv Borderlanders: Enabling Mobile Women and Girls for Safe Migration and Citizenship Rights, at 5-6, U.N. Doc. CM/MMW/2003/ CRP.3 (Jan. 14, 2004) (prepared by Jyoti Sanghera).

27. Sassen, supra note 13 , at 258. 
role" to global capital in ways that either directly or indirectly foster these gendered-labor networks. ${ }^{28}$ Favored growth strategies include attracting direct foreign investment from MNCs and their subcontracting networks-often sacrificing labor standards to do so--or investing in tourism industries widely associated with recruitment of trafficked females for the entertainment of foreign tourists. ${ }^{29}$ Moreover, in an effort to ease their unemployment problems and accumulate foreign currency earnings, deeply indebted countries make use of their comparative advantage in the form of women's surplus labor and encourage their labor force to seek employment in wealthier countries. ${ }^{30}$ Through their work and remittances, women enhance the government revenue of deeply indebted countries, ${ }^{31}$ helping to "narrow the trade gap, increase foreign currency reserves, facilitate debt servicing, reduce poverty and incqualities in wealth and support sustainable development." 32

\section{B. Immigration "Pull" Factors}

The growth in trafficking reflects not just an increase of "push" factors in the globalized economy, but also the strong "pull" of unmet labor demands in the wealthier destination countries. Most have an aging population, with "[t]he proportion of adults over 60 in high income countries... expected to increase from eight per cent to 19 per cent by 2050 , while the number of children will

28. Vidyamali Samarasinghe, Confronting Globalization in Anti-Trafficking Strategies in Asia, Brown J. World Aff., Summer-Fall 2003, at 91 , 94 (citing Jim Mittleman, The Globalization Syndrome: Transformation and Resistance 15 (2000)).

29. Id. at 92,94 .

30. Id. at 95.

31. Sassen, supra note 13, at 258. Thus, according to Professor Sassen, "[t]he growing immiseration of governments and whole economies in the global south has promoted and enabled the proliferation of survival and profit-making activities that involve migration and trafficking of women." Id. at 255 (from the Abstract). According to the International Organization for Migration, remittances through official channels totaled $\$ 93$ billion in 2003, INTERNational Organization for Migration, World Migration 2005: Costs and Benefits of International Migration 491 (2005), approached $\$ 100$ billion in 2004, id. at 124 , and now seriously rival development aid in many countries; unofficial remittances are likely to be two to three times that figure. For example, in El Salvador, "remittances accounted for more than 80 per cent of the total financial inflows in 2000 , with overseas development assistance and foreign direct investment accounting for less than 20 per cent." Kaye, stupra note 9, at 14.

32. KAYE, supra note 9, at 14 (spending remittances on locally produced goods and services can have a multiplier effect by simulating demand). 
drop by one third" due to low fertility rates. ${ }^{33}$ The resulting "labour shortages, skills shortages, and increased tax burdens on the working population... to support and provide social benefits to the wider population," ${ }^{34}$ means these economies will become increasingly dependent on migrant populations to fill the labor gaps. ${ }^{35}$ A number of other factors strengthen the immigration "pull," including, for example, fewer constraints on travel (for example, less restrictions on freedom of movement and cheaper and faster travel opportunities); established migration routes and communities in destination countries plus the active presence of recruiters willing to facilitate jobs or travel; and the promise of higher salaries and standards of living abroad.$^{36}$ Advances in information technology, global media, and internet access provide the means to broadcast to even the most isolated communities the promise of better opportunities abroad. ${ }^{37}$ This fosters high hopes and expectations of women from poor, unskilled backgrounds who are desperate for employment. ${ }^{38}$ The prospect of any job is a strong "pull" factor for survival migrants.

Labor shortages in the informal sector are often filled by migrant workers, who are willing to take the "3-D jobs"-i.e., jobs that are dirty, dangerous, and difficult-rejected by the domestic labor force. ${ }^{39}$ The employers' profit potential, particularly in the case of trafficked persons, is much higher than would be the case if local labor were employed. If trafficked persons are paid at all, it is invariably at a lower rate than local workers would require, and the trafficked persons do not receive the costly benefits required in many Western states. ${ }^{40}$

In addition to the cost differential, migrants' "foreignness" appears to be a factor in the demand for migrant workers in the domestic work and commercial sex sectors. As Professors Anderson and O'Connell Davidson report in a recent study of the "demand side" of trafficking, employers favor migrant domestic workers over local domestic workers because of the vulnerability and lack of

\section{Id. at 13 .}

34. Id.

35. "In order to stabilise the size of the working population in the $15 \mathrm{EU}$ member states, there needs to be a net inflow of some 68 million foreign workers and professionals between 2003 and 2050." Id. (citing Int'l Org. for Migration, World Migration 2003, at 245 (2003)).

36. Id. at 11 ; accord Boswell \& CRISP, supra note 24 , at 10.

37. Samarasinghe, supra note 28 , at $96-97$.

38. See Boswell \& CRISP, supra note 24, at 6.

39. See ILO Global Report, supra note 3, at 46.

40. See Taran, supra note 12, at 15-16. 
choice that results from their foreign status. ${ }^{41}$ Employers perceive them as more "flexible" and "cooperative" with respect to longer working hours, more vulnerable to "molding" to the requirements of individual households, and less likely to leave their jobs. Moreover, their racial "otherness" makes the hierarchy between employer and employee less socially awkward-it is easier to dress up an exploitative relationship as one of paternalism/maternalism towards the impoverished "other." +2

Rather than publicly recognize their dependence on migrant labor (skilled and unskilled), destination countries have sought instead to promote increasingly restrictive immigration policies, particularly in the wake of the September 11,2001 , terrorist attacks in the United States. There remains considerable public and political resistance to liberalizing the migration policies of these countries, ${ }^{43}$ despite strong demographic and economic evidence that migrants produce more benefit than burden for their host countries. ${ }^{* 4}$ This resistance is linked to popular - yet mistaken-concerns about the negative impact of immigration flows on employment, national security, welfare systems, and national identity. ${ }^{45}$ Rather than confront xenophobic reactions to issues of migration, many governments instead have sought electoral or political advantage by promoting increasingly restrictive immigration policies. ${ }^{46}$ The tension between economic reality and political expedience thus fosters conditions that enable and promote human trafficking. In reducing the opportunities for regular migration, these policies provide greater opportunities for traffickers, who are "fishing in the stream of migration," to take advantage of the confluence of survival migrants' need for jobs, on the one hand, and the unrelenting market demand for cheap labor, on the other. ${ }^{47}$ Indeed, as borders close and migration routes become

41. Bridget Anderson \& Julia O'Connell Davidson, Is Trafficking in Human Beings Demand Driven?: A Multi-Country Pilot Study 29-32 (Int'l Org. for Migration, IOM Migration Research Series No. 15, 2003).

42. Id. at 32 .

43. Boswell \& CRISP, supra note 24 , at 1 .

44. INT'L ORG. For Migration, supra note 31 , at 170, 188-89 (noting that a recent U.K. study calculated that in 1999-2000, migrants contributed $\$ 4$ billion more in taxes than they received in benefits, and a U.S. study estimated that national income had expanded $\$ 8$ billion in 1997 because of immigration).

45. Boswell \& CRisp, supra note 24, at 21-22.

46. KaYE, supra note 9, at 13.

47. Helen Thomas, Fishing in the Stream of Migration, ADB Rev. (Asian Dev. Bank, Manila, PhiL.), February 2004, at 16, 16-17, available at http://www.adb.org/Documents/Periodicals/ ADB_Review/2004/vol36_1/fishing.asp. 
more dangerous, smuggling costs increase to the point that smugglers turn to trafficking to make a profit. ${ }^{48}$

Situating the trafficking phenomenon in this broader context spotlights how deeply rooted trafficking is in the underlying socioeconomic forces that impel workers to migrate. It also demonstrates how the focus on the back end of the trafficking process- that is, entry of the trafficker and the abuses committed in the course of the trafficking-is but a narrow snapshot of the broader problem of trafficking. Solutions that fail to account for the broader picture can only hope to ameliorate the symptoms, rather than address the cause of the problem.

\section{The International Legal Response}

Throughout the 1980s and 1990s, human rights advocates worked diligently to draw attention to the problem of trafficking in its broader socioeconomic context. ${ }^{49}$ But it was concern over the national security implications of increased labor migration and the involvement of transnational criminal syndicates in the clandestine movement of people that ultimately motivated governments to take action. Viewing trafficking as a border and crime control issue, governments seized the opportunity to develop a new international countertrafficking law in the form of a trafficking-specific protocol to a new international cooperation treaty to combat transnational crime-the U.N. Convention Against Transnational Organized Crime (Crime Convention). ${ }^{50}$ States' eagerness to combat the problem resulted in the conclusion of the U.N. Protocol

48. Migrant smuggling entails payment by a third party to facilitate the movement of the migrant. See Protocol Against the Smuggling of Migrants by Land, Sea and Air, Supplementing the United Nations Convention Against Transnational Organized Crime, G.A. Res. 55/25, annex III, pmbl. \& art. 3, U.N. Doc. A/RES/55/25 (Nov. 2, 2000) [hereinafter Migrant Smuggling Protocol]. In addition to whatever profit is to be made from the facilitated migration, traffickers can also profit from the revenue generated from the exploitative end purpose of the movement-e.g., the forced labor or slavery-like practice.

49. See generally Human Rights Watch, A Modern Form of Slavery: Trafficking of Burmese Women and Girls into Brothels in Thailand (1993), available at http://www.hrw.org/ reports/1993/thailand/; Human Rights Watch, Rape for Profit: Traffickinc of Nepali Girls AND WOMEN TO INDIaN Brothels (1995), available at http://www.hrw.org/reports/pdfs/c/crd/ india957.pdf (report by Human Rights Watch demonstrating that unequal access to education and employment opportunities, among other factors, fed the feminization of poverty and migration and increased women's vulnerability to traffickers).

50. United Nations Convention Against Transnational Organized Crime, G.A. Res. 55/25, annex I, U.N. Doc. A/RES/55/25 (Nov. 2, 2000) [hereinafter Crime Convention]. 
to Prevent, Suppress and Punish Trafficking in Persons, Especially Women and Children (Palermo Protocol or Protocol) within two years and its entry into force three years later, on December 25, 2003. ${ }^{51}$

The development of the Protocol set the stage for a rapid proliferation of counter-trafficking laws in the past five years. The issue of human trafficking now high on the agenda, the international community has devoted hundreds of millions of dollars in trafficking interventions. ${ }^{52}$ Efforts to combat trafficking have proceeded from a narrow view of trafficking as a criminal justice problem, with a clear focus on targeting the traffickers and, to a lesser extent, protecting their victims. Addressing the socioeconomic factors at the root of the problem, by contrast, has largely fallen outside the purview of government action.

\section{A. The Palermo Protocol}

The Palermo Protocol is, at base, an international crime control cooperation treaty designed to promote and facilitate States Parties' cooperation in combating trafficking in persons. Together with the Crime Convention, the Protocol establishes concrete measures to improve communication and cooperation between national law enforcement authorities, engage in mutual legal assistance, facilitate extradition proceedings, and establish bilateral and multilateral joint investigative bodies and techniques. ${ }^{53}$ While the criminal justice aspects of this framework are a clear priority, the Palermo Protocol also contains measures to protect trafficked persons and to prevent trafficking. Unlike the criminal justice measures, which are couched as hard obligations, these provisions are mostly framed in programmatic, aspirational terms. Thus, "in appropriate cases and to the extent possible under its domestic law," the Protocol requires states to consider implementing measures providing for trafficked persons' physical and psychological recovery and endeavor to provide for their physical safety, among other goals. ${ }^{54}$ With respect to "prevention" efforts, states are to endeavor to undertake measures such as information campaigns and social and economic initi-

51. Protocol to Prevent, Suppress and Punish Trafficking in Persons, Especially Women and Children, G.A. Res. 55/25, annex II, U.N. Doc. A/RES/55/25 (Nov. 2, 2000) [hereinafter Palermo Protocol].

52. See 2005 TIP REPORT, supra note 14, at 245 (reporting that the United States alone has invested $\$ 295$ million in counter-trafficking efforts over the last four fiscal years).

53. Crime Convention, supra note 50, arts. 16, 18, 19,27, 28.

54. Palermo Protocol, supra note 51, arts. 6-8. 
atives to prevent trafficking, ${ }^{55}$ as well as "to alleviate the factors that make persons...vvulnerable to trafficking, such as poverty, underdevelopment and lack of equal opportunity," and to discourage demand for trafficking. ${ }^{56}$

Just as the text of the Protocol reflects states' clear prioritization of the criminal justice response, so does that which was excluded from the Protocol. Human rights advocates lobbied to include a provision in the Protocol granting trafficked persons protections against prosecution for status-related offenses, such as illegal migration, undocumented work, and prostitution, ${ }^{57}$ citing the well-documented reality that trafficked persons were frequently deported or jailed rather than afforded protection. ${ }^{58}$ But states refused to include such a provision for fear that it would lead to the "unwarranted use of the 'trafficking defense' and a resulting weakening of states' ability to control both prostitution and migration flows through the application of criminal sanctions." 59

States' concern over maintaining strong border controls was also reflected in their efforts to draw a legal distinction between trafficking and migrant smuggling, ${ }^{60}$ despite the difficulty in distinguishing between the two in practice. Defined as the illegal movement of persons across borders for profit, "migrant smuggling" technically applies to any trafficked person who begins his/her journey as a smuggled migrant but is ultimately forced into an exploitative labor situation. ${ }^{61}$ Consequently, a victim of incomplete trafficking-for example, a victim who is stopped at the border before the end purpose of the movement is realized-could be treated as a smuggled migrant and thus denied the victim

55. Id. art. $9,92$.

56. Id. art. 9, III 4-5.

57. See Position Paper on the Draft Protocol to Prevent, Suppress and Punish Trafficking in Women and Children, submitted by the Special Rapporteur on Violence Against Women, Report of the Ad Hoc Committee on the Elaboration of a Convention Against Transnational Organized Crime on its Fourth Session, Held in Vienna June 28 to July 9, 1999, U.N. Doc. A/AC.254/CRP.13 (May 20, 1999) [hereinafter "Coomaraswamy Position Paper"].

58. See, e.g., Coomaraswamy Report, supra note 1, If 44.

59. See Anne Gallagher, Human Rights and the New UN Protocols on Trafficking and Migrant Smuggling: A Preliminary Analysis, 23 Hum. RTs. Q. 975, 991 (2001).

60. See Migrant Smuggling Protocol, supra note 48 (migrant smuggling is the subject of one of the other two protocols to the Crime Convention).

61. Smuggling is defined as "the procurement, in order to obtain, directly or indirectly, a financial or other material benefit, of the illegal entry of a person into a State Party of which the person is not a national or a permanent resident." Id. art. 3. 
status and protections afforded to trafficked persons. ${ }^{62}$ As Anne Gallagher concludes, the Protocol drafters' failure to address this issue was "clear evidence of [states'] unwillingness ... to relinquish any measure of control over the migrant identification process." 63

States' refusal to adjust their migration control policies is perhaps symptomatic of states' deep reluctance to expand the rights afforded to migrant workers. Tellingly, it took thirteen years for the International Convention on the Protection of the Rights of All Migrant Workers and Members of their Families (the Migrant Workers Convention) to receive enough ratifications to enter into force on July $1,2003 .{ }^{6+}$ By contrast, the Palermo Protocol entered into force three years after its adoption. ${ }^{65}$ Despite well-documented abuses of migrant workers' rights in countries of destination, these countries discouraged ratification of the instrument on grounds that its provisions - which address the treatment, welfare, and human rights of migrant workers (documented and undocumented) and their families - are too ambitious and detailed to be practicable and realizable. ${ }^{66}$ That states would maintain such a restrictive stance even when the violations are egregious enough to constitute trafficking reveals the strong priority placed on the crime and border control aspects of trafficking over concern for the welfare of trafficked persons.

\section{B. Counter-trafficking Efforts in Practice}

In practice, the priorities set forth in the Palermo Protocol are mirrored in counter-trafficking law and policy initiatives undertaken across the globe. As the U.S. State Department's yearly Trafficking in Persons Report (TIP Report) reveals, most countries' counter-trafficking efforts focus on effectuating a strong criminal justice response to the problem. ${ }^{67}$ Although there is a growing aware-

62. "Smuggled migrants are assumed to be acting voluntarily," and are thus afforded less protection under international law. Anne Gallagher, Trafficking, Smuggling and Human Rights: Tricks and Treaties, 12 Forced Migration Rev. 25, 26 (2002).

63. Gallagher, supra note 59 , at 1001.

64. For a current list of ratifications, see http//untreaty.un.org/ENGLISH/bible/ englishinternetbible/partI/chapterIV/treaty25.asp.

65 . For a current list of ratifications, see http:/www.unodc.org/unodc/en/crime_cicp_ signatures_trafficking.html.

66. Taran, supra note 12, at 18-22.

67. 2005 TIP REPORT, supra note 14, at 34 . 
ness of a need for stronger protection of trafficked persons' human rights ${ }^{68}$ current models of protection continue "to prioritise the needs of law enforcement over the rights of trafficked persons." ${ }^{69}$ Most governments adopt restrictive immigration policies, which, at times, fail to distinguish between smuggling and trafficking and can lead to summary deportation or incarceration of trafficked persons. ${ }^{70}$ This not only exposes trafficked persons to further harm, including possible retrafficking, but it deprives them of access to justice and undermines government efforts to prosecute the traffickers. ${ }^{71}$ To the extent trafficked persons are afforded an opportunity to remain in the destination countries, their residency status is often conditioned on their willingness to assist in the prosecution of their traffickers, potentially exposing them to further trauma and reprisals from the traffickers.

Even well-intentioned efforts to adopt a more "victim-centered approach"72 to the problem can promote a narrow conception of trafficking that diverts at-

68. The United States, for example, is increasingly recognizing how the failure to protect trafficked persons' human rights compromises efforts to prosecute traffickers. For example, noting the significant disparity between the numbers of people trafficked to the United States $(14,500$ 17,500 each year) and the numbers of those who have reported the abuse to law enforcement (757 as of November 2003), the U.S. Department of Justice has made concerted efforts to collaborate more effectively with NGOs and consider more victim-centered approaches to prosecution. Dep'T of Justice, Assessment of U.S. Activities to Combat Trafficking in Persons 5, 22, 26-27 (2004).

69. Elaine Pearson, Anti-Slavery Int'l, Human Traffic, Human Rights: Redefining Victim Protection 4 (2002).

70. See, e.g., U.S. Dep't of State, Trafficking in Persons Report 148, 165, 185 (2004) (citing the Italian, Portuguese, and British governments' failure to distinguish between trafficking and smuggling). The 2004 Trafficking in Persons Report also described how trafficked persons in the Czech Republic "were treated as illegal immigrants and expressed fear of testifying due to safety concerns," id. at 134, and in Morocco, were "jailed and/or detained for violating immigration or other laws [and were] not provided adequate legal representation." Id. at 199. In the 2005 Trafficking in Persons Report, Italy, the United Kingdom, and Portugal persisted in their failure to distinguish between trafficking and smuggling or illegal immigration. 2005 TIP REPORT, supra note 14, at 130, 181, 221. France has apparently adopted a practice of "arresting, jailing, and fining trafficking victims as a means of discouraging the operation of trafficking networks and to gain information to pursue cases against traffickers," which, as the U.S. State Department notes, "harms trafficking victims and allows for [their] deportation ... regardless of possible threats [in their country of origin]." Id. at 106.

71. Pearson, supra note 69, at 2.

72. See 2005 TIP RePORT, supra note 14, at 5 (referring to the "three P's" of prosecution, protection, and prevention, noting that "a victim-centered approach to trafficking requires us equally to address the 'three R's'-rescue, rehabilitation and reintegration"). 
tention from its broader labor and migration causes and implications. A review of country practices reveals two trends, in particular, that foster this dynamic: (1) the deliberate de-emphasizing of the movement or recruitment element of the trafficking definition; and (2) an over-emphasis on sex trafficking, to the neglect or exclusion of labor trafficking.

Regarding the first trend, the United States, for example, has adopted an interpretation of the trafficking definition that shifts focus away from the movement or recruitment element to the "end purpose" of the trafficking:

The means by which people are subjected to servitude-their recruitment and the deception and coercion that may cause movement - are important factors but factors that are secondary to their compelled service. It is the state of servitude that is key to defining trafficking.... The movement of [a] person to [a] new location is not what constitutes trafficking; the force, fraud or coercion exercised on that person by another to perform or remain in service to the master is the defining element of trafficking in modern usage. ${ }^{73}$

Granted, de-emphasizing the recruitment or movement aspect of the definition perhaps helps draw much-needed attention to the broader problem of forced labor. But it also has the detrimental effect of diverting attention from the fact that trafficking is a crime committed during migration and against migrants. It also departs from the international legal definition of trafficking, of which movement or recruitment of the person is a defining element:

[Trafficking is defined as] (a) ... the recruitment, transportation, transfer, harbouring or receipt of persons, by means of the threat or use of force or other forms of coercion, of abduction, of fraud, of deception, of the abuse of power or of a position of vulnerability or of the giving or receiving of payments or benefits to achieve the consent of a person having control over another person, for the purpose of exploitation. Exploitation shall include, at a minimum, the exploitation of the prostitution of others or other forms of sexual exploitation, forced labour or services, slavery or practices

73. Id. at 9-10. 
similar to slavery, servitude or the removal of organs; (b) the consent of a victim of trafficking to the intended exploitation set forth in subparagraph (a) shall be irrelevant where any of the means set forth in subparagraph (a) have been used. ${ }^{74}$

The migration element of the definition speaks to the particular vulnerability that migrants face as a result of living and working in an unfamiliar milieu, where language and cultural barriers can prevent the migrant from accessing assistance. ${ }^{75}$ De-emphasizing the migration aspect of trafficking thus overlooks a substantial source of vulnerability. It also narrows the focus of state responsibility to the confines of that which has taken place within its borders-that is, the exploitative end purpose of the facilitated movement. Moreover, it conveniently sets to the side thorny questions regarding how to address a victim's (often undocumented) immigration status-an issue of immediate and pressing concern to trafficked persons, who often fear return to their home communities. In sum, this formulation glosses over any responsibility on the part of the state for fostering emigration push or immigration pull factors discussed in Part I, above.

As for the second trend, despite the fact that the international legal definition of trafficking encompasses trafficking for nonsexual as well as sexual purposes, many states - including, until recently, the United States ${ }^{76}$ - have focused their efforts on trafficking for sexual purposes. ${ }^{7}$ Significantly less attention has been devoted to "labor trafficking" or trafficking for nonsexual purposes, despite recent estimates that this practice accounts for at least one-third of all trafficking cases. ${ }^{78}$ The moral outrage that images of women trapped in "sexual slavery" so easily provoke has been a galvanizing force behind global efforts to

74. Palermo Protocol, supra note 51, art. 3.

75. See Coomaraswamy Position Paper, supra note 57, at 3.

76. In the 2005 TIP REPORT, the United States expanded its coverage of trafficking for nonsexual purposes. 2005 TIP Report, supra note 14, at 1 . This expansion was undoubtedly in response to years of NGO protests over the United States' focus on sex trafficking.

77. Frank Laczko, Introduction, Int'L Migration, Jan. 2005, at 5, 9 (introduction to a special issue entitled "Data and Research on Human Trafficking: A Global Survey," noting that research on trafficking has focused on the sex trafficking of women and children, neglecting other forms of trafficking). Liz Kelly, "You Can Find Anything You Want": A Critical Reflection on Research on Trafficking in Persons Within and into Europe, Int'L Migration, Jan. 2005, at 235, 239 (article in a special issue entitled "Data and Research on Human Trafficking: A Global Survey," noting how most of the content and data in the TIP Reports issued by the U.S. State Department for years 2002-2004 was "confined to sexual exploitation").

78. ILO Global RePort, supra note 3, at 46. 
combat trafficking. Sex trafficking and its associated sex crimes also fall neatly within the purview of a criminal justice response. By contrast, labor trafficking, though hardly benign, is perhaps less likely to engender a criminal justice response given our arguably greater moral tolerance for exploitative labor conditions. An over-emphasis on sex trafficking thus not only risks overlooking a significant portion of the trafficked population, but it diverts attention away from states' responsibility to promote safe labor conditions.

If protection of the victims is of secondary concern to states, then prevention of trafficking (at least, in the long term) is practically an afterthought. Despite the Protocol's requirement that states should take measures to alleviate the root causes of trafficking, such as "poverty, underdevelopment and lack of equal opportunity,"79 in practice, "prevention" efforts focus on short-term strategies such as public awareness campaigns regarding the risks of migration. For instance, in her ground-breaking study assessing prevention efforts in southeastern Europe (SEE),${ }^{80}$ Barbara Limanowska found a tendency to adopt "repressive" prevention strategies that "focus on suppressing the negative (or perceived as negative) phenomena related to trafficking, such as [undocumented migration] ... illegal and forced labor, prostitution, child labor or organized crime." ${ }^{81}$ Common strategies include bar raids, computerized border checks and databases that register the names of undocumented migrants, and public awareness campaigns that broadcast to the general public the risks of trafficking. ${ }^{82}$ While efforts to prevent $r e$-trafficking of victims are more victim-focused-providing housing, social services, and legal and medical assistance to victims to assist in reintegration into their home communities-these are only provided on a short-term basis. ${ }^{83} \mathrm{As}$ Limanowska has concluded with respect to SEE, "[t] $]$ here is no comprehensive long-term prevention strategy for the region, nor any clear understanding of what such a strategy should include." ${ }^{84}$ Although prevention strategies from other regions of the world have yet to be assessed in as comprehensive a fash-

79. Palermo Protocol, supra note 51, art. 9, I 4.

80. Barbara Limanowska, Trafficking in Human Beings in South Eastern Europe xiii (2005) [hereinafter SEE RePort] (assessing prevention strategies in Albania, Bosnia and Herzegovina, Bulgaria, Croatia, the former Yugoslav Republic of Macedonia, Moldova, Romania, Servia and Montenegro, and Kosovo).

81. Id. at 2.

82. See generally SEE REPORT, supra note 80.

83. Id. at 36-37.

84. Id. at xiii. 
ion, ${ }^{85}$ a review of the country practices in other regions of the world reveals a similar focus on repressive approaches to prevention. ${ }^{86}$

Preliminary evaluation of these strategies indicates that they are ineffective, if not counterproductive. Rather than deterring risky migration, large-scale public awareness campaigns have been dismissed by their target audiences as antimigration measures resulting from "the manipulation of the anti-trafficking agenda by rich countries that want to keep the poor away from their territory." ${ }^{\circ}$ Efforts to "reintegrate" trafficked persons into their home communities cannot overcome the grim reality that the underlying social conditions that led to their trafficking-such as poverty and unemployment-still exist. Indeed, the myopic failure to recognize, much less address, the root causes of trafficking can actually increase vulnerability to trafficking. For example, as Limanowska reports with respect to SEE, the failure to link domestic violence to trafficking at the policy level has led to the creation of separate shelters for trafficked persons and victims of domestic violence, with the former underutilized and the latter underfunded and overcrowded. ${ }^{88}$ Rather than recognizing domestic violence as a possible early warning sign of trafficking, the closing of domestic violence shelters has gone unaddressed, thus increasing the vulnerability to trafficking of an already at-risk population.

States' resistance to addressing the broader social problems that feed human trafficking is, in some respects, unsurprising. Treating trafficking as a criminal justice issue is far less resource-intensive and politically risky than developing long-term strategies to address the labor migration aspects of the problem. Moreover, addressing the socioeconomic root causes of trafficking means confronting vexing questions concerning the measure and content of states' obligations to achieve "progressive realization" of the social, economic, and cultural rights half of the human rights corpus. ${ }^{89} \mathrm{~A}$ long-term strategy would thus require attention to deeper, systemic problems that states have proven highly reluctant to confront-for example, the economic need to migrate and the polit-

85. The SEE REPoRT is one of the few to undertake an assessment of prevention programs. As the IOM found in its survey of data and research on trafficking, there is a lack of information regarding trafficking programs in many regions of the world, including the Middle East, the Americas, and Africa. See Laczko, supra note 77, at 7.

86. See generally 2005 TIP REPORT, supra note 14.

87. SEE REPORT, supra note 80 , at 22.

88. Id. at $20-21$.

89. International Covenant on Economic, Social and Cultural Rights, G.A. Res. 2200, U.N. GAOR, 21 st Sess., Supp. No. 16, at 49, U.N. Doc. A/6316 (Dec. 16, 1966) [hereinafter ICESCR]. 
ically motivated restrictions against doing so, not to mention the cycle of poverty, discrimination, and violence that causes these migratory flows. As discussed below, however, such a strategy is critical to the success of global efforts to eliminate trafficking.

\section{Prevention as Necessary Core of Counter-trafficking Strategy}

There is no doubt that a strong criminal justice response is a critical component of any effective global counter-trafficking strategy. Absent meaningful victim protection and long-term prevention measures, however, it is, at best, a temporary solution to a chronic and potentially growing problem. ${ }^{90}$ Stopping the vicious cycle of trafficking demands a strategy that frames the problem within its broader socioeconomic context and takes seriously the project of targeting the root causes of this complex problem. As with any call to confront the world's ubiquitous social problems, it is an ambitious task, but one for which a few modest steps could help transform the rhetorical commitment to prevention into a substantive one. Two such measures are proposed and briefly described here.

The first proposed step is to undertake rigorous and independent assessment of the potential long-term effects of existing counter-trafficking strategies. This speaks to the need to ensure that existing counter-trafficking measures do not operate at cross-purposes with the goal of long-term prevention. In their haste to adopt counter-trafficking policies and legislation, governments have largely taken on faith that these strategies are effective with little or no basis in objective evaluations of their outcomes. ${ }^{91}$ The sobering results of the few assessments that have been conducted-such as Limanowska's SEE study and even the United States' self-assessment ${ }^{92}$ - illustrate the critical need for further eval-

90. The current reality is that the number of traffickers arrested is low compared to the efforts expended to capture them, and of those who are tried, few are convicted and even fewer serve sentences. Am. Soc'y of Int'l Law, Trafficking in Humans: Proceedings of the 99th Annual Meeting (forthcoming 2006) [hereinafter 2005 ASIL Human Trafficking Panel] (noting that "virtually no kingpins are brought to justice, and criminal networks remain largely undisturbed," and that sentences are relatively minor and often not served) (draft on file with author). It appears to be a socioeconomic reality that there will be others to take advantage of the substantial profit-making potential to be had wherever there is both economic necessity to migrate, yet shrinking avenues for legal migration. See Sassen, supra note 13, at 266-70.

91. See Laczko, supra note 77, at 9.

92. See generally SEE Report, supra note 80; Dep't of Justice, Assessment of U.S. Activities to Combat Trafficking in Persons (2004). 
uation. With data from at least five years of state practice since the adoption of the Protocol by the U.N. General Assembly, there is now a basis for some preliminary evaluations.

The second is to use international human rights law to provide a conceptual framework for addressing the root causes of trafficking. Framing the project of alleviating the root causes of trafficking as a human rights issue would encourage more proactive efforts to address these problems rather than the traditional assumption that such issues are solely within the province of broader development policy. The Palermo Protocol obliges states to "take or strengthen measures ... to alleviate the factors that make persons ... vulnerable to trafficking, such as poverty, underdevelopment and lack of equal opportunity." ${ }^{33}$ While development policy can provide detailed prescriptions for action on the ground, international human rights law offers an important normative framework within which these strategies can be constructed. Most significantly, a human rights framework offers legal and political space for the disenfranchised to begin to claim these needs as rights, and thereby bring the scope of state responsibility into sharper focus.

\section{A. Assessment of Existing Counter-trafficking Strategies}

A 2003 expert report to the U.N. Commission on the Status of Women concluded that, despite ten years of counter-trafficking laws and policies in the Balkans region, there was no evidence of a significant decrease in trafficking or increase in the number of assisted victims or number of traffickers punished..$^{94}$ Considering the hundreds of millions of dollars spent on counter-trafficking programs around the world-the United States contributed $\$ 96$ million in 2004 alone $\mathrm{e}^{95}$ and the vast numbers of lives affected by trafficking, this conclusion should give us pause. Regrettably, however, as the International Organization

93. Palermo Protocol, supra note 51 , art. $9,94$.

94. U.N. Comm'n on the Status of Women, Women's Human Rights and Elimination of All Forms of Violence Against Women and Girls as Defined in the Beijing Platform of Action and the Outcome Documents of the Twenty-third Special Session of the General Assembly, at 47, U.N. Doc. E/CN.6/ 2003/12 (Mar. 13, 2003) (prepared by Barbara Limanowska). This report was based on information from the Balkans region. Id. at 1 n.2. See also 2005 ASIL Human Trafficking Panel, supra note 90, at 2-3 (noting the disparity between the proliferation of new counter-trafficking legal and institutional mechanisms, on the one hand, and the achievement of meaningful results, on the other).

95. 2005 TIP REPORT, supra note 14, at 1. 
for Migration (IOM) recently reported, "there has been relatively little independent evaluation of counter-trafficking policies and programmes to assess the real impact and effectiveness of different interventions." 96

The few assessments that have been conducted thus far demonstrate why further evaluation of state practices is vital. Studies such as those conducted by Limanowska not only provide critical, pragmatic insight into best (and worst) practices, but they also expose weaknesses and inaccuracies in the ways in which the problem is conceptualized. For instance, Limanowska's findings concerning the ineffectiveness of large-scale public awareness campaigns in the SEE region underscore how these efforts fail to appreciate fully the migrant perspective. That the target audiences of some of these campaigns so readily dismiss them as rich countries' anti-migration propagand $a^{97}$-despite recognizing the accuracy of the risks portrayed-illustrates the depths of the migrants' need to migrate and the great risks they are willing to assume to do so. This is similarly demonstrated in the fact that the vast majority of calls to helplines created to reach victims of trafficking were "preventive and informative"-that is, to seek information regarding migration for work abroad..$^{98}$ Limanowska's evaluation of these and other counter-trafficking initiatives thus underscores governments' chronic failure to appreciate fully the power of the socioeconomic forces underlying migratory flows.

Another area where preliminary studies of programs have called into question the wisdom of existing counter-trafficking strategies relates to efforts to target the demand side of trafficking. Most of these programs are punitive in nature-that is, designed to clamp down on consumer demand, particularly with respect to the commercial sex industry. But as Anderson and O'Connell Davidson demonstrated in their pioneering study of the demand side of trafficking ${ }^{99}$ there are no easy solutions to reducing demand for trafficked laborsexual or nonsexual. On the one hand, clamping down on demand for street prostitution may actually strengthen demand on other segments of the sex industry where trafficked labor can be an issue, such as pornography, escort

96. Laczko, supra note 77, at 9.

97. See supra text accompanying note 87.

98. SEE REPORT, supra note 80 , at $32-33$. On a positive note, however, this experience also suggests the potential preventive role that helplines can play.

99. See generally Anderson \& O'Connell Davidson, supra note 41. 
agency prostitution, lap- and table-dance clubs, etc. ${ }^{100}$ On the other hand, regulating the sex or domestic work sectors "does nothing, in itself, to counteract racism, xenophobia and prejudice against migrants and ethnic minority groups" who tend to comprise the trafficked end of these labor markets and could actually reinforce existing racial, ethnic, and national hierarchies in these sectors. ${ }^{101}$ Accordingly, Anderson and O'Connell Davidson suggest that policy makers "pay much closer attention to the unintended and negative consequences of legislating prostitution ... or of regulating ... domestic work."102 Policy makers instead ought to consider concentrating efforts on educational and preventive work targeting the social construction of demand-that is, the social norms that permit exploitation of vulnerable labor.

In addition to evaluating specific counter-trafficking programs and policies, governments should endeavor to assess their overall priorities vis-à-vis the types of programs they pursue - that is, whether oriented toward short-term or longterm results. The SEE experience reveals that funding for programs tends to be channeled toward anti-migration projects reflecting the interests of countries of destination, or in the alternative, "charity work" focused on direct assistance to victims. ${ }^{103}$ This has had the unfortunate effect of diverting money away from programs focused on development, equality, and human rights, which hold greater promise of long-lasting change. ${ }^{104}$ Trafficking research suffers from the same shortsightedness. Most of the research in the trafficking field is "actionoriented" or designed to prepare for specific counter-trafficking interventions on the ground, typically conducted within a six-to nine-month time frame. "There has been less funding for long-term research [into] the causes of trafficking and the best ways to prevent and combat it, or [into] the impacts of different interventions and policy responses." 105

The importance of rigorous and independent assessment of existing counter-trafficking programs and research cannot be underestimated. Obtain-

100. Id. at 43. Reports of the Swedish experience illustrate this point. "[W]hen Sweden introduced laws in 1999 to criminalize men who purchase sex, while decriminalizing [the prostitutes/ sex workers], the incidence of female sex trafficking dropped .... [W] [Wile the demand for prostitution decreased in Sweden, it increased in neighboring countries. The male clients simply went [elsewhere to satisfy their desires]." Samarasinghe, supra note 28, at 102.

101. Anderson \& O'Connell Davidson, supta note 41 , at 44.

102. Id. at $46,47$.

103. SEE REPORT, supra note 80 , at 54.

104. Id.

105. Laczko, supra note 77 , at 9. 
ing meaningful results requires a deeper understanding of the problem and the operational value of the proposed solutions than currently exists today.

\section{B. Addressing Root Causes through a Human Rights Lens}

Although there is a general understanding that trafficking has its root causes in poverty, unemployment, discrimination, and violence against women, no large-scale counter-trafficking program has been implemented to address these underlying problems. ${ }^{106}$ Even at the level of legal analysis, there is a persistent failure to analyze how international human rights law could be used to address the root causes of the problem. While resource limitations might necessarily slow the implementation of programs targeting root causes on the ground, no such barrier exists to articulating a legal framework to address root causes. Emerging norms and analysis in the field of women's human rights, specifically, and economic, social, and cultural rights, generally, provide a basis upon which such a framework might be developed. Utilizing the principle of nondiscrimination is one potential avenue, as described briefly below.

When one considers trafficking in its broader socioeconomic context, it is not difficult to connect the root causes of trafficking to violations of economic, social, and cultural rights. These include violations of such rights as the right of opportunity to gain a living by work one freely chooses or accepts, the right to just and favorable conditions of work, the right to an adequate standard of living, and the right to education. ${ }^{107}$ Race- and gender-based discrimination in the recognition and application of these rights are also critical factors rendering women particularly vulnerable to trafficking. ${ }^{108}$ Many of the rights implicated in the root causes of trafficking are the subject of states' obligations under the International Covenant on Economic, Social, and Cultural Rights (ICESCR). With women arguably encountering the most severe deprivations in the area of economic, social, and cultural life, ${ }^{109}$ the Convention on the Elimination of All

106. See 2005 ASIL Human Trafficking Panel, supra note 90 , at 3.

107. ICESCR, supra note 89 , arts. $6,7,11,13$.

108. See generally Convention on the Elimination of All Forms of Discrimination Against Women, G.A. Res. 34/180, U.N. Doc. A/RES/34/180 (Dec. 18, 1979), reprinted in 19 I.L.M. 33 (1980).

109. Katarina Frostell \& Martin Scheinin, Women, in Economic, Social and Cultural Rights 331, 331 (Asbjørn Eide et al. eds., 2d. rev. ed. 2001). 
Forms of Discrimination against Women (CEDAW) also plays a critical role in safeguarding these rights vis-à-vis women.

As readily identifiable as these rights violations are, however, legal analyses of trafficking have persistently neglected the economic, social, and cultural rights implications of trafficking. This likely has to do with the fact that, despite being touted as indivisible, interdependent, interrelated, and of equal importance for human dignity, ${ }^{110}$ the norm development, monitoring, and implementation of economic, social, and cultural rights-half of the human rights corpus-has fallen far behind that of civil and political rights. The traditional view of economic, social, and cultural rights as merely "programmatic" or "aspirational" in nature - in contrast to the apparently immediately realizable civil and political rights-has fed their marginalization in human rights discourse. Vexing questions and enduring debates over the justiciability of economic, social, and cultural rights-or their capacity to be subject to formal third-party adjudication with remedies for noncompliance ${ }^{11}$-a a another likely cause of this relative neglect.

Evolving jurisprudence regarding economic, social, and cultural rights, generally, and their application to women, specifically, nonetheless provides a basis for at least conceptualizing a legal framework to address the root causes of trafficking. The traditional assumption that economic, social, and cultural rights are inherently aspirational, necessarily resource-intensive, and therefore not immediately realizable, has now been cast into doubt. ${ }^{112}$ By distinguishing between the types or levels of obligations human rights impose on States Parties-to respect, to protect, and to fulfill-commentators have demonstrated how certain aspects of economic, social, and cultural rights can be of immediate effect. ${ }^{113}$ Many of these rights can be safeguarded by virtue of states' noninterference with the freedom and use of resources possessed by individuals. Accordingly, the Committee on Economic, Social and Cultural Rights (the treaty body charged with monitoring state compliance with the ICESCR) has made clear that states have an immediate

110. World Conference on Human Rights, June 14-25, 1993, Vienna Declaration and Programme of Action, art. 1, I 5, U.N. Doc. A/CONF.157/23 (July 12, 1993), reprinted in 32 I.L.M. 1663 (1993). 111. See Martin Scheinin, Economic and Social Rights as Legal Rights, in Economic, Social and Cultural Rights, supra note 109, at 29, 29; Dennis \& Stewart, supra note 4, at 463.

112. See, e.g., Asbjørn Eide, Economic, Social and Cultural Rights as Human Rights, in Economic, Social and Cultural Rights, supra note 109, at 9, 23-25.

113. See U.N. Comm'n on Econ., Soc. and Cultural Rights, General Comment 3, annex III, II 10, U.N. Doc. E/1991/23 (Dec. 14, 1990) [hereinafter General Comment 3]. "Progressive realization" cannot be used as a "pretext for non-compliance." The Maastricht Guidelines on Violations of Economic, Social and Cultural Rights, reprinted in 20 Huм. RTs. Q. 691,694 (1998). 
obligation to ensure that ICESCR rights be exercised without discrimination. ${ }^{114}$ Thus, states are obliged to abolish any laws, policies, or practices that affect enjoyment of these rights and, moreover, to take action to prevent discrimination by private persons and bodies in any field of public life.

Interpreted to have broad application under international human rights law, the nondiscrimination principle is particularly well-suited to a human rights analysis of the broad range of root causes of trafficking - poverty, unequal educational and employment opportunities, and violence against women, among others. Under the International Covenant for Civil and Political Rights, states are obliged not only to refrain from discriminatory practices, but also to adopt punitive measures to make equality and nondiscrimination a concrete reality. ${ }^{115}$ As General Comment 18, issued by the Human Rights Committee, makes clear, the prohibition on discrimination in law or in fact applies "in any field regulated and protected by public authorities," and thus encompasses economic, social, and cultural rights. ${ }^{116}$ In practice, the nondiscrimination principle has been applied to prohibit gender-based differential treatment in the allocation of social benefits, such as unemployment benefits. ${ }^{117}$ It has also provided a framework for addressing genderbased violence, "or violence that is directed against a woman because she is a woman or that affects women disproportionately." ${ }^{118}$ Poverty is another root cause of trafficking to which the nondiscrimination principle can be applied, as "poverty not only arises from a lack of resources - it may also arise from a lack of access to resources, information, opportunities, power, and mobility ... [D]iscrimination may cause poverty, just as poverty may cause discrimination." 119

As discussed above in Part I, discrimination against women with respect to educational and employment opportunities, the disproportionate burden economic restructuring places on women, the feminization of migration due to violence against women, and the feminization of poverty, among other factors, render women particularly vulnerable to trafficking. "Gender-based discrimination [of-

114. General Comment 3, supra note 113, If 1.

115. See International Covenant on Civil and Political Rights, G.A. Res. 2200, art. 26, U.N. GAOR, 21 st Sess., Supp. No. 16, at 52, U.N. Doc. A/6316 (Dec. 16, 1966).

116. See Frostell \& Scheinin, supra note 109, at 334 (citing General Comment 18).

117. Id. at $334 \&$ n.15.

118. U.N. Comm. on the Elimination of All Forms of Discrimination Against Women, General Recommendation 19, U.N. Doc. HRI/GEN/Rev.3 (noting that "[p]overty and unemployment increase opportunities for trafficking in women").

119. United Nations, Office of the High Comm'r for Human Rights, Human Rights and Poverty Reduction: A Conceptual Framework 17 (2004). 
ten] intersects with discriminations based on other forms of 'otherness,' such as race, ethnicity, [and] religion," among others. ${ }^{120}$ The nondiscrimination principle, particularly as articulated, interpreted, and applied by treaty bodies such as the Committee on the Elimination of Discrimination against Women (Women's Committee) and the Committee on the Elimination of Racial Discrimination, thus offers a useful framework for addressing the root causes of trafficking.

Moreover, the recent entry into force of the CEDAW Optional Protocol contributes to the practical appeal of a nondiscrimination approach to root causes. The Optional Protocol provides individuals alleging violations of their CEDAW rights the opportunity to pursue complaints against States Parties to the Optional Protocol, and for the Women's Committee to conduct inquiries into allegations of systematic and gross violations of those rights. ${ }^{121}$ Using the discrimination framework thus affords rare access to an enforcement mechanism otherwise unavailable for violations of economic, social, and cultural rights.

\section{Conclusion}

Situated within its broader frame, the problem of human trafficking demands that efforts to combat this international crime and human rights violation take seriously the need to address its root causes. Over a decade of global counter-trafficking initiatives adopting a "law and order" approach to the problem has yielded questionable, if not disappointing, results. The international community is coming to the growing realization that treating trafficking predominantly, if not solely, as a border and crime control issue is but to respond only to a snapshot view of a much larger problem. There is no question that confronting the poverty, unemployment, discrimination, and gender-based violence, among other factors, that increase an individual's vulnerability to trafficking is a tremendous task that demands creative and long-term strategic thinking. This article has provided a cursory view of two possible approaches by which we might begin to undertake this project. Far more analysis and deeper understanding of the trafficking problem are necessary prerequisites of the project, as is dispossessing ourselves of the traditional view that realization of economic, social, and cultural rights can wait. As daunting of a task as this may be, it is a necessary one if global efforts to eliminate trafficking are to succeed.

120. Coomaraswamy Report, supra note 1, \ 55.

121. See Optional Protocol to the Convention on the Elimination of All Forms of Discrimination Against Women, G.A. Res. 54/4, annex, U.N. Doc. A/54/49 (Oct. 6, 1999). 